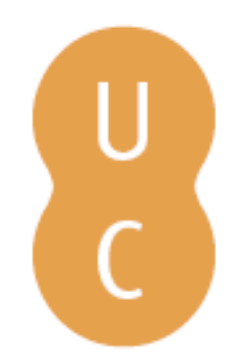

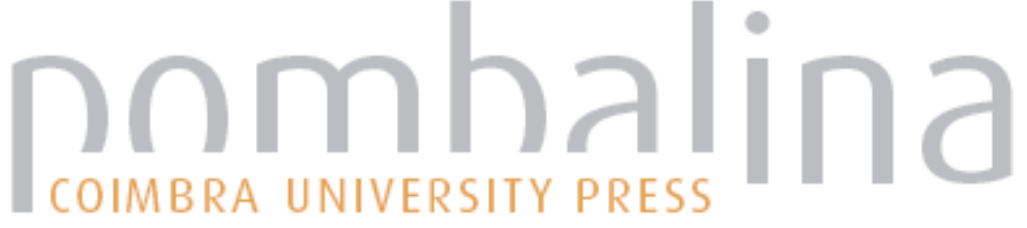

\section{Contradictory aspects of tourism in historic centres: pelourinho revisited}

\author{
Autor(es): $\quad$ Cifelli, Gabrielle; Peixoto, Paulo
}

Publicado por: Imprensa da Universidade de Coimbra

URL

persistente: URI:http://hdl.handle.net/10316.2/37363

DOI: $\quad$ DOI:http://dx.doi.org/10.14195/978-989-26-0754-2_11

Accessed : $\quad$ 21-Sep-2017 10:32:59

A navegação consulta e descarregamento dos títulos inseridos nas Bibliotecas Digitais UC Digitalis, UC Pombalina e UC Impactum, pressupõem a aceitação plena e sem reservas dos Termos e Condições de Uso destas Bibliotecas Digitais, disponíveis em https://digitalis.uc.pt/pt-pt/termos.

Conforme exposto nos referidos Termos e Condições de Uso, o descarregamento de títulos de acesso restrito requer uma licença válida de autorização devendo o utilizador aceder ao(s) documento(s) a partir de um endereço de IP da instituição detentora da supramencionada licença.

Ao utilizador é apenas permitido o descarregamento para uso pessoal, pelo que o emprego do(s) título(s) descarregado(s) para outro fim, designadamente comercial, carece de autorização do respetivo autor ou editor da obra.

Na medida em que todas as obras da UC Digitalis se encontram protegidas pelo Código do Direito de Autor e Direitos Conexos e demais legislação aplicável, toda a cópia, parcial ou total, deste documento, nos casos em que é legalmente admitida, deverá conter ou fazer-se acompanhar por este aviso.

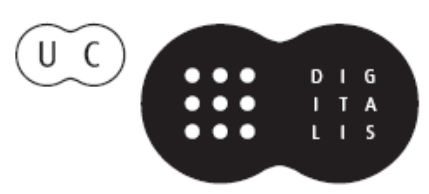




\section{GABRIELLE CIFELLI}

Universidade Cruzeiro do Sul

gcifelli@gmail.com

PAULO PEIXOTO

CES, Universidade de Coimbra

pp@uc.pt

\section{CONTRADICTORY ASPECTS OF TOURISM}

IN HISTORIC CENTRES: PELOURINHO REVISITED

\section{Introduction}

Urban intervention projects in rundown central areas of significant historical, artistic and cultural value are a new aspect of contemporary urban planning which aim to create greater visibility for certain sections of city territory by enhancing their cultural references in order to reverse the physical and social decay into which they have fallen and to boost their economy.

These strategies, adopted in recent decades in rundown areas in various European countries and in the United States, have been reproduced since the 1990s in cities in Latin American countries with the aim of combining local development with heritage preservation. Therefore, in many historic centres in large and medium-sized cities, investments destined to promote culture aim to increase their attractiveness in terms of tourism in order to boost this activity which, theoretically, leads to the creation of jobs and income by enhancing and marketing material and non-material cultural references.

In Brazil, these initiatives have taken place in some central areas of recognised heritage value, such as the historic centres of Recife and Salvador. They have also been converted into ways of boosting the economy 
in central areas of major Brazilian cities such as Rio de Janeiro and São Paulo, where projects are being implemented in which tourism is one of the economic activities being promoted. Amongst these projects, the one which is nowadays attracting the most attention due to its contradictory features is the Integrated Action Plan for the Historic Centre of Salvador (Plano de Ação Integrada do Centro Histórico de Salvador), drawn up by the state government under the direction of Antônio Carlos Magalhães during the 1990s.

The measures developed under this plan, which was executed in an area of the historic centre of Salvador known as Pelourinho, aimed primarily to transform this site into one of the most important tourism centres in Salvador and in Bahia itself, but, as is the case with many other projects with the same intentions, this did not take place as expected.

Repeatedly and increasingly viewed as a socially exclusive territorial development strategy, the intervention became one of the most symptomatic projects to take place in Brazil, demonstrating that tourism and heritage do not always converge as focal points for territorial development. It is therefore worth critically assessing the effects of this plan on the socio-territorial dynamics of the historic centre of Salvador, focussing principally on the relationship between tourism, heritage and local development.

\section{The process of producing and appropriating the historic centre of Salvador}

As the original capital city of Brazil until 1763, in the early years of Portuguese colonial rule the city of Salvador was considered the main centre of political power in the colony, a status it maintained until the capital was transferred to Rio de Janeiro. In addition to wielding significant political power, Salvador was also home to an economic elite that consisted of enterprising individuals and wealthy traders, the majority of whom conducted their business activities in the city, considered one of the few urban centres to exist in the colony until the mid 18th century. The Catholic Church also exercised power there, seeking to impose its 
hegemony over the religious beliefs and practices introduced by black Africans.

The territorial configuration of Salvador and, in particular, its original nucleus, located in the so-called Cidade Alta which is nowadays considered the historic centre of the city, reflects the power structure in force during the colonial period, the time when most of the buildings were constructed. Its landscape, socially constructed over time, was built and ordained by the power of the dominant social institutions, in this case the Portuguese state, the church and the economic elite.

Its spatial forms, represented by imposing storied mansions, churches and public and institutional buildings, were key elements in future processes of creating identity and establishing a collective memory officially constructed by the state through institutional recognition of the heritage value of many of the buildings. It therefore operated as a form of material culture, ensuring the symbolic value of Salvador within Brazilian culture and the colonial memory. According to Duarte Paes (2009: 166), it is through landscape that these legacies and memories, transformed into heritage, acquire a material form. This materiality, representative of time and space, remains as form in the landscape, but is continually refunctionalised to meet current purposes. The process of refunctionalisation is linked to the various ways in which buildings are used over time, remaining closely linked to changes in the socio-economic profile of their residents and users.

Until the mid 19th century the historic centre of Salvador, principally the Pelourinho area, was inhabited by the dominant class whose power and wealth was reflected in the grandeur and magnificence of the buildings. Administrative, residential and commercial uses predominated in this area of the city, characterised by its significant economic dynamism and its political and administrative importance, since the main public administration activities were concentrated there. However, at the end of the 19th century the city expanded southwards with the creation of new, more modern, neighbourhoods and consequently new centres, a process which resulted in the transfer of a considerable section of the wealthier population to these new areas of urban expansion. 
The abandonment of buildings by the wealthier population, the fall in property values and the lack of public investment in infrastructures led to a change in the socio-economic profile of the historic centre, subsequently occupied by a low-income population without the financial means to take care of the physical maintenance of the buildings, which soon began to deteriorate, in many cases ruining their original character.

During the 20th century, increasing poverty and the physical deterioration of the historic centre resulted in the area gaining a bad reputation and, by the mid 1930s, it had become known as an area of prostitutes and slum dwellers (Brooke, 1993 apud Santos Junior and Braga, 2009).

This process of evolution, development and deterioration of central areas has occurred with a certain intensity in the large and medium-sized urban centres of cities with differing levels of socio-economic development. According to Smith (2007: 21), this form of restructuring urban space is the result of the centralisation of capital in suburban areas, leading to the development of industrial, commercial, residential and recreational activities, a fact that also leads to a rise in the price of land. Less and less capital is therefore invested in maintaining and restoring buildings in the central areas, leading to a reduction in the price of land and buildings which, in turn, results in a loss of economic dynamism and the social deterioration of these sites.

In the historic centre of Salvador this process took place throughout the 20th century, worsening in the 1960s and 1970s with the relocation of its administrative and commercial operations to other centres for economic development within the muncipality. ${ }^{1}$ As in other urban centres in Brazilian cities, this section of the territory and, in particular, Pelourinho, became an area in which countless social problems were concentrated, with high rates of violence, crime, prostitution, drug trafficking and social exclusion.

During this period the recognition by IPHAN of the heritage value of numerous buildings in the historic centre resulted in the creation of

${ }^{1}$ Bahia. Governo do Estado. Secretaria de Cultura. Escritório de Referência do Centro Antigo. UNESCO. 2010, Centro Antigo de Salvador: Plano de Reabilitação Participativo./ Escritório de Referência do Centro Antigo, UNESCO. - Salvador : Secretaria de Cultura, Fundação Pedro Calmon, p. 18. 
strategies to encourage tourism, taking advantage of the centre's cultural and symbolic potential.

The mission to convert Pelourinho into a centre for tourism is the result of projects that emerged at the end of the 1960 s aiming to combine heritage, tourism and territorial development through the implementation of the 1969 General Plan for the Recovery of the Pelourinho Area (Plano Geral de Recuperação da Área do Pelourinbo). In other words, in Salvador as in many other places, the expansion of the urban fabric and the creation of new central nuclei and prime zones also created the conditions for installing the most stigmatised individuals and functions in the old centre. At the same time, the heritage-tourism combination was discovered as the remedy for local urban policies. According to Sant'Anna (2003: 45),

"despite over twenty years of public investment which, for better or for worse, paved the way for its appropriation as a tourism and cultural centre, at the beginning of the 90s the situation in the historic centre remained more or less the same as it had been at the end of the $60 \mathrm{~s}$ ".

This initiative, which was unsuccessful, falls within the perspective of tourism-based development of central areas of heritage value supported by international conservation bodies and debated in important international meetings dedicated to formulating principles and strategies for the conservation and preservation of heritage. Within this context, it is worth emphasising the role of the 1967 Norms of Quito, whose presuppositions reinforce cultural tourism as a means of preserving the built heritage and reversing the deterioration of historic areas in Latin American countries, whilst assuming respect for the social needs of the local population (Santos Junior \& Braga, 2009).

Since the start of its work of surveying historic sites and monuments established as World Heritage Sites, UNESCO has always drawn attention to the importance of tourism as an activity capable of creating the conditions required to protect heritage assets, given the lack of financial resources and staff within national preservation organisations. This perspective may be highlighted in the reports by Michel Parent, a technician from the 
Department for the Inspection of Monuments and Sites in France, who worked in Brazil from 1966 to 1967 on a UNESCO mission that aimed to provide aid and technical assistance to the then National Historic and Artistic Heritage Department (Departamento do Património Histórico e Artístico Nacional) to support work associated with cultural heritage of Brazil (Leal, 2008: 13-14).

Whilst visiting the main urban sites declared National Heritage Sites by the federal preservation body, Parent emphasised the country's great potential for developing cultural tourism at a time in which the federal government was taking its first steps towards creating policies to encourage tourism with the foundation of the Empresa Brasileira de Turismo - EMBRATUR (Brazilian Tourist Board).

On a visit to Salvador, Michel Parent defined the city as "one of the most amazing art cities in the world" where the cultural traditions were so varied and lively that "the specific cultures of Brazil can be witnessed by visitors" (Leal, 2008: 26).

This acknowledgement of the historical and cultural importance of the historic centre of Salvador was legitimised by the official recognition of Pelourinho and the surrounding area by IPHAN in 1984, and the recognition of the same area as a UNESCO World Heritage Site in 1985, on the basis of Criteria IV and VI. ${ }^{2}$ This gave Pelourinho and the other historic centres established as World Heritage Sites differential status due to their supposed uniqueness and outstanding character.

The process of statutory differentiation conferred on heritage assets on the basis of an appreciation of particular attributes such as uniqueness and authenticity increases their capacity to generate financial returns that benefit the local area, since their enhanced cultural value adds economic value to heritage, and tourism, in many cases, becomes a dynamic force within this process. In this sense, Harvey (2005), in exploring considerations regarding the mechanisms for attributing monetary value to material

2 Criterion IV - an outstanding example of a type of building, architectural ensemble or landscape which illustrates (a) significant stage(s) in human history. Criterion VI - directly or tangibly associated with events or living traditions, with ideas or with beliefs, with artistic and literary works of outstanding universal significance. 
and non-material cultural references, states that the degree of uniqueness and authenticity of products and sites ensures them a monopoly revenue, on the basis of heightening their distinctive features.

According to this author, in order to become competitive on the international market by attracting flows of people and capital, cities seek to enhance their symbolic capital with the aim of generating distinctive features than can increase their power of attraction and provide them with a certain economic advantage (Harvey, 2005: 232-233). This perspective has been consolidated on the level of territorial marketing around the idea of "brand image".

Recognition of a city or some of its cultural references as a Heritage Site is one of the main strategies used for this purpose, even when the alleged degree of authenticity and uniqueness is more enduring as an idealised discourse than a concrete reality. Efforts are therefore made to turn an internationally recognised and institutionally established cultural heritage into a commodity representative of a memory, identity and tradition, reinvented in many cases, with the aim of redeeming an idealised past. With their colours and outlines heightened through images and discourse propagated by the media, these cultural assets help raise the level of competitiveness of cities striving to attract capital. It should be emphasised that the role and intervention of UNESCO itself has fostered these dynamics.

As Peixoto emphasises (2006: 41), "within this logic of product promotion, heritage has become an inevitable resource in strategies used to define a brand image, establishing itself as a 'brand' that defines a certain competitive and communicable value".

Furthermore, the assessment of distinctive value through the establishment of a collection of assets or sites such as Pelourinho as Heritage Sites does not ensure a financial return for the area if is not accompanied by a series of strategies created principally by the public authorities in order to plan and execute the necessary intervention work designed to enhance its potential to attract and seduce by drawing in cultural consumers.

The promotion of culture has therefore become one of the main strategies used by urban authorities to help boost the economies of urban 
centres and Salvador has not escaped this precept. However, before investing in the cultural sphere, it is necessary to reverse the deterioration of the heritage and reduce the social problems typical of the historic centre. The state government therefore became responsible for this initiative, with the aim of transforming Pelourinho and the rest of the historic centre of Salvador into an important centre for tourism.

\section{The Integrated Action Plan for the Historic Centre of Salvador: aims and intentions}

In 1992, aiming to boost the economy of Pelourinho through tourism and, at the same time, to reflect an image of an enterprising government in tune with new trends in urban planning with a cultural emphasis, the state government of Bahia, under Antônio Carlos Magalhães, initiated an urban intervention plan focussing mainly on Pelourinho which was designed to transform the area into a new centre for economic development, in which tourism would be responsible for generating employment and income.

The Integrated Action Plan for the Historic Centre of Salvador (Plano de Ação Integrada do Centro Histórico de Salvador), executed by the Instituto do Património Artístico Cultural da Bahia - IPAC (Bahia Cultural Artistic Heritage Institute) Institute and the Companhia de Desenvolvimento Metropolitano de Salvador (Salvador Metropolitan Development Company), involved a series of measures aimed at physically restoring the rundown historic buildings, creating cultural facilities, generating government incentives for the installation of commercial establishments and services dedicated to tourists and visitors, and promoting cultural entertainment strategies.

The interventions included the physical recovery of 600 properties (Sant'Anna, 2003: 46) located in Pelourinho and the surrounding area. The work was carried out on the most important properties and involved restoration, the renovation of buildings, changes to interiors whilst maintaining the facades and overall dimensions, and the conservation of 
properties already in good condition. ${ }^{3}$ In addition to recovering the buildings, the intervention also involved painting the facades in a variety of colours which did not respect the original tones of the buildings, in order to enhance their aesthetic and visual features. The presupposition behind the strategy was to make individual buildings and urban groupings stand out more in the landscape, reinforcing the scenic emphasis of heritage in this type of intervention.

During this period, termed late capitalism by Jameson (1996), the overvaluing of image and allegorical representation of history acquired great economic significance and made architectural heritage one of its main means of expression. The distinctively different colours of the historic buildings served as a means of strategically embellishing cities (Arantes, 2001), making them more likely to be consumed as cultural commodities. This fact is even more significant given this is a model that circulates globally and is subject to the phenomenon of the escalation of the visual.

This type of strategy, governed by an appreciation of the aesthetic aspect of heritage, falls within the framework of the logic of an intervention which Motta (2000) terms a globalised model, in which heritage, transformed into a commodity and a cultural attraction, becomes the target of interventions governed by "fachadista" (superficial) aspects whose objective consists of "targeting the consumer (...) using the cultural asset as a commodity to attract or to support the consumption of other commodities" (Motta, 2000: 270). This perspective, together with the appreciation of heritage scenery and the growing importance of visual consumption, constitutes the framework for the incentives to install cultural facilities and commercial and services establishments serving the interests of tourists and visitors in the historic buildings of Pelourinho.

Since the power of a territory to serve as a tourist attraction is not merely restricted to its natural, historical and cultural features, but also involves the group of infrastructures, services and commercial activities

3 Bahia. Governo do Estado. Secretaria de Cultura. Escritório de Referência do Centro Antigo. UNESCO. 2010, Centro Antigo de Salvador: Plano de Reabilitação Participativo./ Escritório de Referência do Centro Antigo, UNESCO. - Salvador: Secretaria de Cultura, Fundação Pedro Calmon, p. 92. 
which support this activity, it was necessary, in the case of Pelourinho, to invest in implementing and providing an economic impetus for these activities. The state government therefore became responsible for managing the new ways of using this portion of territory on the basis of strategies aimed at the tourism-based refunctionalisation of the cultural heritage (Cifelli, 2010). In order to respond to market dictates, old methods acquire new functions related to the use of the territory for tourism.

Pelourinho attracted private investment by offering a series of competitive advantages introduced by the government and designed to boost its economy, with the aim of transforming the area into an open-air shopping centre (Sant 'Anna, 2003: 47), a model that has, moreover, been insinuated into many other similar interventions. The area in question, principally located between Terreiro de Jesus and the Largo do Pelourinho, became the main locus for the concentration of cultural and economic activities associated with the promotion of culture and tourism in the historic centre of Salvador, accommodating numerous cultural facilities such as museums, galleries, arts centres and foundations, and countless handicraft and souvenir shops. These were mainly destined for the commercialisation of Afro Bahian culture, in the form of arts and music spectacles and a range of goods displayed in the facades of the buildings. The growing adaptation to the tourist market is clearly evident in the ways in which goods are displayed, sold and even manufactured (including miniature versions of the goods on sale, to make them easier for tourists to transport).

In this and many other cases of urban intervention in historic centres, heritage becomes the setting for the dynamics of consumption and the street, the prime public space, "is turned into a network organised by/ for consumption. Here the speed at which pedestrians circulate, although tolerated, is determined and defined by opportunities for window-shopping and purchasing the objects on display" (Lefebvre, 2004: 31). Any attempt to understand the historic and cultural references of the buildings becomes, in a great many cases, secondary to the fascination and seduction of the commodity format.

The cultural entertainment strategies for Pelourinho were led by the "Dia \& Noite" project, which involved promoting cultural activities such 
as plays, festivals, events and, principally, concerts held in public squares. The attraction of highly popular Bahian artists and regular performances by world famous musical groups such as Olodum, considered representative of Bahian culture, assume a commercially strategic purpose, since they bestow a cultural identity on Pelourinho, or "Pelô", as it is usually called, that is strengthened by being in the spotlight of the highly popular shows featured in the media. The global market for world music and the stereotyped identification of Brazil and the Brazilians as producers of lively and colourful musical rhythms has fostered an image appropriate for a tourism market based on authenticity and entertainment.

The many paid attractions are a means of selecting audiences by taking their greater consumer potential into account. In this way, the area is "put on stage and turned into a stage" through the use of cultural enhancement and entertainment strategies to increase the number of visitors (Choay, 2001: 224).

The restoration of a positive image to Pelourinho and Bahian culture, as displayed by the state government, amends a certain public consensus regarding the economic and cultural relevance of such interventions. However, its actions and intentions neglect the social contradictions inherent to the process of commercialising heritage.

The measures undertaken by the state government in the 1990s deliberately denied the local population the opportunity to qualify for the economic bonus resulting from the process. Whilst the interventions gave priority to the restoration and renovation of buildings and improvements to local infrastructures or, in other words, whilst it concerned itself with the material aspects of the urban area, social problems in Pelourinho were still very much in evidence. As an alternative to ameliorate the problem, the government offered a transfer scheme for local residents which included modest sums in compensation and was aimed at their relocation to other residential areas outside the intervention area. According to Fernandes (2006), fourteen years after the start of the project, approximately 2,909 families were removed from the intervention area, implying a reduction in the residential use of the buildings. 
This draining of the local population of Pelourinho and the rest of the historic centre of Salvador can be seen in the results of the 2000 Census. According to these figures, in 2000 only $2.8 \%$ of soteropolitanos ${ }^{4}$ lived in neighbourhoods in the historic centre of Salvador and its surrounding area. 5

From the start of the intervention work, which was executed in seven phases, it was obvious that residential use of the buildings was not considered a priority in the plan to promote tourism and boost the economy of Pelourinho. Priority was therefore given to enhancing the formal aspects of the buildings to the detriment of the range of uses and meanings socially ascribed to heritage.

The hegemony of the tourism-based refunctionalisation of the cultural heritage deprived the local population of their actual means of economic survival, given that popular commerce was rejected in favour of promoting incentives that favoured the installation of commercial establishments and services dedicated to tourism, and informal trading was increasingly suppressed by the authorities. Repressive police tactics were adopted as one of the means of banning individuals and activities considered "undesirable" by the state in terms of the proposals to convert Pelourinho into the major consumer, culture and leisure centre in Salvador.

In promoting the creation of a new pattern of cultural consumption linked to the commodification of heritage (Paes Luchiari, 2006), the process of social selection which this and other urban intervention projects began to impose led to socially exclusive ways of using heritage and appropriating territory, which tended to impoverish the social and cultural diversity of such areas, an aspect that would also ensure they were increasingly attractive in terms of tourism.

\footnotetext{
${ }^{4}$ Soteropolitan is the demonym for those born in Soteriopolis (a city in Ancient Greece founded by Soterios). In Latin "Soterios" means "Salvador" (Saviour) and, by extension, the inhabitants of Salvador are known as soteropolitanos.

5 Bahia. Governo do Estado. Secretaria de Cultura. Escritório de Referência do Centro Antigo. UNESCO. 2010, Centro Antigo de Salvador: Plano de Reabilitação Participativo./ Escritório de Referência do Centro Antigo, UNESCO. - Salvador: Secretaria de Cultura, Fundação Pedro Calmon, p. 169.
} 


\section{The territorial dynamics of tourism in the historic centre of Sal- vador: conflicts and contradictions}

The strategy for reconciling tourism and territorial development in areas which have become heritage sites has not always enjoyed the success hoped for by the state and the tourism developers. The reduction in the diversity of uses of heritage and the socially exclusive ways of appropriating territory have culminated in a new phase of economic, physical and social decay in these areas. In the historic centre of Salvador, principally in Pelourinho, this process has been evident since the beginning of the 2000s, when the economic returns from tourism were not as high as expected. As this activity was considered by the state and the urban planners to be the principal means of boosting the economy of the historic centre, it was concluded that the process had been unsuccessful due to certain contradictory aspects of the intervention. According to Fernandes (2006, $\mathrm{s} / \mathrm{n}$ ), the proposal to transform Pelourinho into an enormous open-air shopping centre,

"ran counter to all the criticisms that had pervaded urban planning since the 1960 s, namely the fight against a monofunctional approach, considered undesirable in urban dynamics that are more rational - in terms of a more intensive use of infrastructures - and complex".

The prevalence of commercial and services establishments dedicated to tourism $^{6}$ and the establishment of a new dynamic of territorial organisation governed by stimulating consumerism led to a growing need to attract an increasingly substantial consumer public into the area. Although a major publicity machine was developed to promote Pelourinho as a leading

6 The information on the characterisation of the facilities and services destined for tourism in the historic centre of Salvador is based on information contained in the following: Bahia. Governo do Estado. Secretaria de Cultura. Escritório de Referência do Centro Antigo. UNESCO. 2010, Centro Antigo de Salvador: Plano de Reabilitação Participativo./ Escritório de Referência do Centro Antigo, UNESCO. - Salvador: Secretaria de Cultura, Fundação Pedro Calmon. 
historical and cultural centre, certain obstacles reduced the capacity of tourism to boost the local economy, as might have been expected.

In recent years, the tourism flow into Pelourinho has been lower than that expected by the state authorities and market agents. Despite planning, the seasonal nature of the activity has made it difficult to maintain a degree of regularity for the economic profits obtained. In addition, the lack of differentiation and poor quality of the articles sold in the handicraft and souvenir shops and major commercial competition have reduced the financial returns for businesses in the sector, leading to the closure of some existing establishments. Even given these obstacles, Pelourinho and its surrounding area still contains the largest concentration of bars, restaurants, accommodation and cultural facilities in the central area of Salvador.

The low number of tourists has also resulted in insecurity and a lack of access to the existing cultural facilities, given that some museums and churches are closed on weekends and on public holidays, when the greatest number of visitors arrive.

The artificiality of the cultural events staged, including bouts of capoeira that take place only during the short period of time required for tourists to photograph them and Bahian people who wear traditional dress to pose for photographs, and which are made worse by the phenomenon of touting for tourists, ultimately reduces the cultural attractiveness for tourists looking for a meaningful form of contact with more authentic encounters. The more cultural objects and events are subject to imitation, fraud or simulation, the less they offer in terms of generating monopolistic financial returns (Harvey, 2005: 223). In the face of such obstacles to the development of tourism, this activity is becomes less significant in terms of generating employment and income, resulting in a new change to its socio-economic profile.

As Márcia Sant'Anna states (2003: 48), tourists are not the main visitors to this revitalised Pelourinho, but the residents of the central area of Salvador itself, in search of leisure and employment opportunities. Given the difficulties that have been encountered and the closure of shops destined for tourists and wealthier residents, the government is investing in 
cultural entertainment projects. These strategies, adopted with the aim of making Pelourinho more attractive, end up helping to generate work and income for the section of the population residing in the historic centre and surrounding area, boosting popular and street trading.

With regard to the social question, it can be observed that "the authoritarian and socially exclusive nature of the design of the entire programme significantly distances it from the principles of democratic city management" (Fernandes, 2006: s/n). The relocation of the low-income population to other areas of Salvador with the aim of promoting an authentic "social cleansing" of Pelourinho, making it more suitable for cultural, leisure and consumer activities, did not produce the results the government intended, since many of the previous social problems in the area returned when the local population came back to live in the vicinity. Many families who do not have the financial means to rent or buy properties in other neighbourhoods in the city are returning to take up residence again both in Pelourinho and, to a larger extent, in the rest of the historic centre and its surrounding area, in search of better employment opportunities and wages.

The strong ties associated with social life, identity and belonging forged by the population who used to live in the area before the intervention have helped accelerate this process, creating a return to neighbourhood-based relationships and affective bonds between the residents and they area in which they live. However the socially vulnerable circumstances in which most of the population live implies a worsening of the existing social and economic problems. Amongst those most in evidence in the area are robberies and muggings, delinquency, sex tourism, vagrancy, prostitution, the trafficking and consumption of narcotics, mainly crack, and the large numbers of beggars throughout the area, in many cases looking for money to buy illegal drugs.

Faced with this situation, which has intensified in the last five years, a negative image of Pelourinho has superimposed itself over the positive aspects, meaning that it is now described in tourist guidebooks and on travel sites as a rundown, violent area, resulting in an increasing decline in tourist and visitor numbers. 
The social contradictions revealed in the dynamics of the selective and socially exclusive use of areas that have become heritage sites, refunctionalised by and for tourism, leads to conflicts emerging out of disputes between groups over the appropriation of these territories for the free exercise of their social practices and economic activities. This process may be better understood by identifying the various territorialities existing in the areas, such as Pelourinho. According to Campos (2002: 36), territorialities are defined as, a set of actions, individual or group behaviours that tend to affect, influence or control people, phenomena and relationships: activities that establish territories, whose fundamental elements are social representations (the world views of the different social agents, the attribution of meanings and interpretations of reality) and social practices (actions located in space, the everyday materialisation of the identification of groups with spaces subject to planning measures).

By contributing towards the exclusion of unwanted social uses in order to encourage tourism as a hegemonic activity, the kind of territorial planning created on the basis of the Urban Intervention Plan in Pelourinho demonstrated its segregatory nature. In attempting to inhibit and curb the territorialities established by the local population, which are governed by identity, affective, cultural, social and economic bonds with the territory, this plan gave priority to establishing territorialities determined by forms of appropriating the territory for the purposes of tourism, mainly evident during the high season, at weekends and on public holidays.

The superimposition of territorialities generated by tourism over the other territorialised social practices of the local residents prevented the actual cultural richness that comes from a diverse use of territory by a variety of social groups and the free expression of a wealth of existing cultural events from being celebrated in Pelourinho and helping this activities to develop the area's potential as a tourist attraction. However, the serious social problems existing in the historic centre made this kind of integration difficult, resulting in the adoption of palliative measures involving the general expulsion of its residents.

At present, the return of the residents and their economic, social and cultural activities to the area around Pelourinho implies that conflicts may 
emerge between the various territorialities, resulting in tensions and difficulties with the social agents who make hegemonic use of this portion of territory for tourism.

The extensive adjustment of areas to accommodate tourists and the scant attention paid to local residents and users appears to contribute significantly towards creating tensions which, if recurring, culminate in a certain contentious spatial configuration that may be an important variable in understanding the subsequent decline into which these enhanced areas eventually fall (Leite, 2010, p. 84).

Such strategies for the enhancement of Pelourinho and various other historic centres, governed by the tourism-based refunctionalisation of heritage which alters the socio-economic profile of the public who frequent these areas makes it difficult for social groups from different social classes to coexist peacefully and accentuates the alterity between them. This type of relationship may culminate, as is the case in Pelourinho, in increased insecurity, crime, vandalism and other social problems that make management of the democratic uses of heritage, the territory to which it belongs and the collective appropriation of its cultural wealth and the economic benefits resulting from a socially inclusive tourism development plan difficult.

\section{Final considerations}

Very frequently when a direct relationship is established between heritage and territorial development more thought is given to economic development (tourists, visitors, revenue, employment) and less to the development of the local community. If we look closely at situations in which it is easier to recognise a successful relationship between heritage and territorial development, it can be seen that projects based on recovery and the reinforcement of a sense of place are features they have in common. They are projects in which the site itself becomes a project and where the notion of territory is consolidated, in which the city, for example, is not only a tourist destination and a setting, but a tourist destination with a 
story to tell. In other words, it is a territory. It is not only a product, but an experience capable of promoting diverse forms of interaction.

When heritage is put to the service of cities and places, instead of cities and places being used to serve tourism, and when cities are organised with a concern to ensure that their residents benefit and not so much to attract visitors, heritage and territorial development can mutually reinforce each other.

\section{References}

Arantes, O. B. F. 2000, “Uma Estratégia Fatal: A cultura nas novas gestões urbanas". Otília Arantes et al. A Cidade do Pensamento Único: desmanchando consenso. Petrópolis, Vozes, pp. 11-74.

Bahia. Governo do Estado. Secretaria da Cultura; Escritório de Referência do Centro Antigo; UNESCO. 2010, Centro Antigo de Salvador: Plano de Reabilitação Participativo. Escritório de Referência do Centro Antigo, UNESCO. - Salvador: Secretaria de Cultura, Fundação Pedro Calmon.

CAmpos. H. A. 2002, Refletindo sobre o papel das representações nas territorialidades urbanas: o exemplo da área central do Recife. GEOUSP, Espaço e Tempo, São Paulo, n 11, pp. 35-50.

CifelLI, G. 2010, A refuncionalização turística do patrimônio cultural: os novos usos do território apropriado pelo turismo em Ouro Preto - MG, In PAES, M. T. D. Geografia, turismo e patrimônio cultural. São Paulo: Annablume, pp. 113-138. ChOAY, F. 2001, A Alegoria do patrimônio. São Paulo, UNESP - Estação Liberdade. FERnANDes, A. 2006, Projeto Pelourinho: operação deportação x ampliação do direito. Curso de Capacitação - Programas de reabilitação de áreas urbanas centrais. http://www.cidades.gov.br/secretarias-nacionais/programas urbanos/ biblioteca/reabilitacao-de-areas-urbanas-centrais/materiais-de-capacitacao/ curso-de-capacitacao-programas-de-reabilitacao-de-areas-urbanas-centrais-labhab/textos/T_Ana_Fernandes.pdf

Harvey, D. 2005, A produção capitalista do espaço. São Paulo, Annablume.

JAMESon. F. 1996, Pós-modernismo - a lógica cultural do capitalismo tardio. São Paulo, Ática. 
LEITE, R. P. 2010, A exaustão das cidades: antienobrecimento e intervenções urbanas em cidades brasileiras e portuguesas. Revista brasileira de Ciências Sociais, vol 25, n. 72, pp. 73-88.

Lefebvre, H. 2004, A revolução urbana. Belo Horizonte, UFMG.

MotTA, L. 2000, A apropriação do patrimônio urbano: do estético-estilístico ao consumo visual global. Arantes, A.A. (ed.), O espaço da diferença. Campinas: Papirus.

PAes-LuChiARI, M. T. D. 2006, Centros históricos - mercantilização e territorialidades do patrimônio cultural urbano. In: Geographia - Ano 7 - No 14 - 2005, pp. $43-57$.

Peixoto, P. J. M. 2006, O passado ainda não começou. Funções e estatuto dos centros históricos no contexto urbano Português", Sociology PhD thesis. Coimbra: Faculty of Economics, Coimbra University.

LEAL, C. F. B. (org). 2008, As missões da Unesco no Brasil. Rio de Janeiro, IPHAN, 2008.

Sant'Anna, M. A. 2003, Recuperação do Centro Histórico de Salvador: Origens, Sentidos e Resultados. RUA - Revista de Urbanismo e Arquitetura. UFBA Universidade Federal da Bahia, Programa de Pós-Graduação em Arquitetura e Urbanismo. N008. Julho-Dezembro.

SANTOS Junior, W. R; Braga, P. M. 2009, O programa de recuperação do centro histórico de Salvador e as lições das cartas patrimoniais. Arquitextos: São Paulo, 09.107. Vitruvius. Disponível em http://vitruvius.com.br/revistas/read/ arquitextos/09.107/59, acessado em 30 de setembro de 2011.

SMITH, N. 2007, Gentrificação, a fronteira e a reestruturação do espaço urbano. In: GEOUSP - Espaço e Tempo, São Paulo, n 21, pp. 15-31.

Zukin, S. 2000, Paisagens urbanas pós modernas: mapeando cultura e poder. In: Arantes, Antonio. O espaço da diferença. Campinas: Papirus, pp. 80-103. 